\title{
PERAN PEMERINTAH DALAM MELESTARIKAN RITUAL MIWIT ABEH DI DESA DAYU KECAMATAN KARUSEN JANANG KABUPATEN BARITO TIMUR
}

\author{
Effrata \\ Fakultas IImu Sosial dan IImu Politik Universitas PGRI Palangka Raya \\ (email: effrata1970@gmail.com) \\ Firdaus \\ Fakultas IImu Sosial dan IImu Politik Universitas PGRI Palangka Raya
}

\begin{abstract}
Abstrak
Kebudayaan adalah suatu cara hidup yang berkembang dan dimiliki bersama oleh sebuah kelompok orang yang diwariskan dari generasi ke generasi. Budaya terbentuk dari banyak unsur yang rumit, termasuk sistem agama, politik, adat istiadat, bahasa, pakaian, bangunan dan karya seni. Desa Dayu yang memiliki ciri khas upacara ritual yang dikenal dengan Miwit Abeh. Dalam upaya masyarakat tentu perlu dukungan dari pemerintah khususnya pemerintah desa dalam melestarikan ritual Miwit Abeh ini agar tidak musnah di tengah perkembangan zaman. Tujuan dari penelitian ini adalah untuk menganalisis peran pemerintah desa dalam melestarikan ritual Miwit Abeh di desa Dayu, Kecamatan Karusen Janang, Kabupaten Barito Timur serta mendeskripsikan faktor pendukung dan penghambatnya. Penelitian ini menggunakan metode deskriptif. Pendekatan penelitian yang digunakan dalam penelitian yaitu menggunakan pendekatan kualitatif.

Berdasarkan hasil penelitian yang dilakukan ditemukan bahwa Salah satu bentuk dari dukungan dari pemerintah Desa Dayu terhadap tradisi ritual Miwit Abeh yaitu, menyediakan sarana dan prasarana berupa rumah adat dan ikut berpartisipasi melibatkan diri dalam pelaksanaan tersebut. Faktor pendukung dalam melestarikan ritual Miwit Abeh yaitu selain dari peran pemerintah khususnya pemerintah desa juga dari masyarakat desa yang ikut mempromosikan melalui media masa. Faktor penghambat internal yang menjadi penghambat yaitu sikap individu di dalam masyarakat untuk lebih mencintai tradisi sendiri masih sangat rendah, adapun faktor eksternalnya adalah munculnya acara-acara modern seiring perkembangan zaman yang menarik perhatian kaum muda khususnya, sehingga mengurangi minat mereka akan ritual-ritual tradisional yang mereka anggap kuno.

Dapat disimpulkan bahwa peran pemerintah khususnya pemerintah desa sangat mempengaruhi dalam pelestarian budaya-budaya khususnya ritual Miwit Abah yang sudah ada sejak turun temurun. Menjadi tantangan semua pihak baik pemerintah amaupun masyarakat agar bisa menumbuhkan sikap peduli budaya kepada generasi selanjutnya agar ritual seperti Miwit Abeh ini tidak musnah.
\end{abstract}

Kata Kunci: Peran Pemerintah, Pemerintah Desa, Ritual Miwit Abeh

\section{Jurnal Sociopolitico}




\section{Pendahuluan}

Salah satu syarat penting dalam teori pembentukan negara adalah adanya Pemerintah. Pemerintah mempunyai kekuasaan dan berperan sebagai lembaga yang mengurus masalah kenegaraan dan memajukan kesejahteraan rakyatnya. Kearifan lokal dapat didefinisikan sebagai suatu kekayaan budaya lokal yang mengandung arti kebijakan hidup serta pandangan hidup (way of life) yang mengakomodasi kebijakan (wisdom) dan kearifan hidup. Budaya lokal di Nusantara dikenal kearifan lokal yang mengajarkan gotong royong, toleransi, etos kerja, dan seterusnya. Pada umumnya etika dan nilai moral yang terkandung dalam kearifan lokal diajarkan turun-temurun, diwariskan dari generasi ke generasi melalui sastra lisan dan manuskrip.

Provinsi Kalimantan Tengah memiliki kebudayaan yang termasuk dalam kearifan lokal ditiap-tiap kabupaten yang berbeda salah satunya tradisi suku Dayak Ma'anyan yang disebut Manyanggar adalah ritual yang dilaksanakan karena mereka percaya bahwa dalam hidup di dunia, selain manusia juga hidup roh. Kebutuhan untuk membuat tanda-tanda atau batasan dengan roh-roh ini diharapkan agar mereka tidak saling mengganggu kehidupan alami masing-masing dan sebagai ekspresi penghormatan terhadap keterbatasan kehidupan makhluk lain.

Dari berbagai daerah terkhususnya Kabupaten Barito Timur, yang juga memiliki adat-istiadat serta kebudayaan yang berbeda-beda. Wilayah Karusen Janang merupakan salah satu Kecamatan yang ada di Kabupaten Barito Timur yang melingkupi beberapa desa di dalamnya. Dari beberapa desa, desa Dayu yang memiliki ciri khas dari upacara ritual yang dikenal dengan Miwit Abeh. Abeh adalah patung yang awalnya berbentuk manusia dan menyerupai seorang kakek tua, dikeramatkan oleh masyarakat karena pada zaman dahulu di desa Dayu terjadi malapetaka yang masyarakat sebut rume (kiamat). Kejadian tersebut mengagetkan pihak keluarga ataupun masyarakat karena berubahnya seorang kakek menjadi patung sehingga masyarakat menamai patung tersebut dengan Patung Abeh.

Penelitian mengenai ritual Miwit Abeh yang ingin melihat bagaimana peran pemerintah desa dalam melestarikan tradisi ini ditengah-tengah masyarakat Suku Dayak Ma'anyan Kecamatan Karusen Janang Kabupaten Barito Timur. Pada zaman sekarang ini, tidak menutup kemungkinan bahwa nilai-nilai lokal akan terkikis seiring perkembangan yang ada. Maka oleh sebab itu, perlu kiranya tradisi ritual miwit abeh ini di ketahui oleh masyarakat luas tidak hanya dikalangan Suku Dayak Ma'anyan .Selain itu, kecintaan terhadap nilai-nilai budaya lokal semakin berkurang. Padahal niai-nilai lokal merupakan nilai yang mengandung makna yang tinggi bagi penganutnya. Oleh sebab itu, pelestarian budaya di pandang penting untunk tetap menjaga ciri khas suatu daerah sebagai sebuah identitas.

Oleh karena itu penelitian ini diberi judul "Peran Pemerintah Desa Dalam Melestarikan Ritual Miwit Abeh Di Desa Dayu Kecamatan Karusen Janang Kabupaten Barito Timur" guna mengetahui sejauh manakah kepedulian pemerintah terhadap budaya-budaya lokal yang ada. 


\section{Metode Penelitian}

Penelitian ini termasuk dalam jenis penelitian deskriftif di katakan deskriftif karena data yang dikumpulkan berupa katakata,gambar dan bukan berupa angka. Yang menjadi tujuan dari penelitian deskriftif adalah mengupayakan suatu penelitian dengan cara menggambarkan secara sistematis, faktual, dan akurat mengenai fakta dari suatu peristiwa serta sifat-sifat dari individu dan keadaan masyarakat.

\section{Hasil dan Pembahasan}

\section{Peran Pemerintah Desa Dalam Melestarikan Ritual Miwit Abeh di Desa Dayu}

Setelah melakukan penelitian dengan menggunakan teknik pengumpulan data secara observasi langsung dilapangan, dokumentasi, dan wawancara mendalam dengan beberapa narasumber atau informan yang berkaitan dengan penelitian ini, diperoleh data yang berhubungan dengan masalah yang diteliti yaitu peran pemerintah desa dalam melestarikan ritual miwit abeh di Desa Dayu kecamatan Karusen Janang Kabupaten Barito Timur.

Pada mulanya pemerintah Desa Dayu membentuk suatu organisasi desa, yaitu Kepala Desa, Perangkat Desa, dan Badan Permusyawaratan Desa (BPD) yang bekerja sama dengan pemerintah daerah juga Kepala Adat setempat untuk perkembangan kualitas kebudayaan dalam rangka pelestarian nilai-nilai lokal terkhususnya tradisi ritual miwit abeh di Desa Dayu. Kebijakan pemerintah desa membentuk perangkat desa ini termasuk dalam kategori :

1. Merawat, karena adanya Pemerintah Desa maka tokoh-tokoh adat dan masyarakat setempat akan ikut mengurus serta menjagatradisi ritual miwit abeh di Desa Dayu agar tetap ada dan berkembang.

2. Melindungi, karena kebijakan Pemerintah Desa membentuk organisasi dan perangkat desa untuk menyelamatkan tradisi ritual miwit abeh dari kepunahan.

3. Mengembangkan, karena adanya organisasi di Desa Dayu, tradisi akanlebih berkualitas dan bisa mempromosikan tradisi khas suku Dayak Maanyan terkhususnya tradisi ritual miwit abeh yang ada di Desa Dayu Kecamatan Karusen Janang.

\section{Pemerintah Desa Dayu Sebagai Fasilitator}

Pelestarian nilai-nilai lokal yang baik sangat bergantung pada pemerintah yang ada, para tokoh-tokoh adat membutuhkan sarana dan prasarana dari pemerintah desa setempat agar pelestarian tradisi lokal yang ada terkhususnya ritual Miwit Abeh yang ada di Desa Dayu bisa lebih baik dan sempurna. Peran pemerintah desa sebagai fasilitator berdasarkan bentuk pelestarian tradisi lokal masuk dalam kategori, merawat, dengan demikian berarti telah membantu tokoh-tokoh adat untuk menunjang pelestarian tradisi lokal tersebut, melindungi, dengan pemerintah desa menjadi fasilitator artinya pemerintah desa memelihara dan menjaga tradisi lokal yang ada, mengembangkan, karena dengan pemerintah desa memfasilitasi artinya pemerintah menjaga tradisi lokal tersebut agar lebih baik dan lebih maju serta berdampak positif untuk tradisi lokal itu sendiri,masyarakat dan sekitarnya.

\section{Jurnal Sociopolitico}


Peran Pemerintah Desa dalam Acara Rutin Ritual Miwit Abeh di Desa Dayu

Pemerintah desa bersama dengan perangkat desa, juga Kepala adat Desa Dayu saling bekerjasama mempersiapkan dan mengadakan acara rutin ritual miwit abeh di Desa Dayu jika sudah tiba saatnya. Masyarakat sekitar Desa Dayu juga ikut berpartisipasi dalam hal ini walaupun seperti yang kita ketahui dilihat dari pesatnya kemajuan teknologi dan seiring dengan berkembangnya gaya hidup masyarakat pada saat ini banyak yang lupa akan adat istiadat ataupun tradisi yang ada. Tetapi tidak dengan tradisi yang ada di desa Dayu Kecamatan Karusen Janang masyarakat sangat percaya dengan sesuatu yang bersifat sakral dan dianggap mempunyai nilai keramat oleh sebab itu pemerintah desa, perangkat desa, kepala adat, serta masyarakat sangat menjaga dan melestarikan tradisi tersebut karena sudah di anggap menjadi suatu kebiasaan turun temurun bagi masyarakat Desa Dayu. Acara rutin ritual miwit abeh yang di laksanakan pada bulan juli setiap tahun nya adalah salah satu cara agar tradisi lokal yang ada di Desa Dayu tidak hilang ataupun punah. Peran Pemerintah Desa sangat diperlukan dalam hal ini, karena dengan diadakan nya acara rutin ritual miwit abeh berarti menyelamatkan tradisi yang ada di Desa Dayu agar tetap ada dan berkembang walaupun di hadapi dengan era globalisasi dan perkembangan zaman yang semakin maju. Serta mengembangkan tradisi ritual miwit abeh ini agar lebih maju dan tetap tenar di daerah Kabupaten Barito Timur dan suku Dayak Ma'anyan terkhusunya bagi masyarakat Desa Dayu agar tidak terjadinya hal yang tidak diinginkan ataupun merugikan masyarakat setempat karena tradisi ritual miwit abeh merupakan upacara yang sakral.

\section{Faktor Pendukung Dalam Pelestarian Tradisi Ritual Miwit Abeh di Desa Dayu}

1. Pemerintah Desa Dayu

Pemerintah Desa melibatkan diri dan mengajak masyarakat setempat dalam upaya pelestarian dan pengembangan tradisi tersebut. Pemerintah Desa memberikan kesempatan yang sama kepada Kepala AdatDesa Dayu untuk berpartisipasi dalam menjaga dan melestarikan tradisi ritual miwit abeh. Sehinggamasyarakat tidak saja dapat meningkatkan kesejahteraannya namun secara tidak langsung masyarakat juga dilibatkan dalam upaya pelestarian kebudayan lokal. Salah satu bentuk dari dukungan dari pemerintah Desa Dayu terhadap tradisi ritual miwit abeh yaitu, menyediakan sarana dan prasarana berupa rumah adat dan ikut berpartisipasi melibatkan diri dalam pelaksanaan tersebut.

\section{Masyarakat Desa Dayu}

Masyarakat Desa Dayu memiliki hubungan erat dengan tradisi ritual miwit abeh, karena yang sering bernazar ataupun menahur hajad adalah masyarakat. Begitu juga untuk melestarikannya masyarakat sangat berperan penting dalam hal ini. Sebab, manusia yang telah berkumpul dalam suatu tempat atau daerah disebut dengan masyarakat dan yang menciptakan tradisi, maka masyarakat juga yang harus menjaga, mempertahankan dan melestarikan tradisi tersebut. Salah satu ciri masyarakat yang maju adalah kemampuan mereka dalam menjaga dan melestarikan tradisi yang ada di Desa Dayu Kecamatan Karusen Janang.

\section{Media Massa}

Karena adanya media massa, sebuah tradisi dapat berkembang dan tetap dilestarikan juga dikenal oleh banyak orang 
salah satunya yaitu,tradisi ritual miwit abeh di Desa Dayu yang dulu hanya di ketahui oleh segelintir orang dan desa yang ada di sekitar Kabupaten Barito Timur sekarang semakin berkembang dan di kenal oleh berbagai daerah bahkan sudah banyak yang melakukan penelitian terkait upacara ritual miwit abeh karena sejarahnya yang begitu menarik dan mengesankan.Berkat adanya media massa yang menjadi sarana pemberitaan atau publikasinya dalam aneka wujud postingan foto, video yang beredar di internet, berita,artikel, tentang tradisi ritual miwit aneh yang ada di Desa Dayu sekarang menjadi dikenal oleh banyak orang bahkan sudah diterbitkan oleh Dinas Kebudayaan dan Pariwista Kabupaten Barito Timur pada tahun 2017 yang berjudul "Upacara Ritual Miwit Abeh".

Faktor Penghambat Dalam Pelestarian Tradisi Ritual Miwit Abeh di Desa Dayu

1. Faktor Internal

Faktor internal yang menjadi penghambat yaitu sikap individu didalam masyarakat untuk lebih mencintai tradisi sendiri masih sangat rendah, terkadang pola hidup individual yang telah dihadapkan dengan perkembangan zaman yang semakin modern menjadi faktor penyebab minimnya kecintaan ataupun kesadaran untuk tetap menjaga dan melestarikan sebuah tradisi yang ada, seperti halnya tradisi ritual miwit abeh yang ada di Desa Dayu Kecamatan Karusen Janang. Tradisi yang sudah turun temurun dilaksanakan setiap tahunnya sudah tidak asing lagi bagi masyarakat Desa Dayu, namun ada saja yang beranggapan hal tersebut biasa saja dikarenakan terpengaruh oleh tradisi yang bersifat nonlokal.

2. Faktor Eksternal

Suatu realita dalam kehidupan pada masa sekarang terlebih bagi generasi muda saat ini akibat pengaruh perkembangan zaman yaitumereka lebih cendrung pada menonton konser-konser musik pop, lagu band, dance dan sebagainya dibandingkan dengan menghadiri atau menyaksikan langsung upacara tradisi Ritual Miwit Abeh. Realita kehidupan generasi muda saat ini merupakan produk modernismesemakin kurang tertariknya terhadap hal-hal yang berbau tradisi, segala sesuatu yang berkaitan dengan tradisi dianggap kuno, ketinggalan zaman dan hanya milik generasi sebelumnya saja. Pada hakikatnya tradisi merupakan produk asli para leluhur dan terkandung banyak nilainilai tersendiri, seperti hal nya dengan ritual miwit abeh yang ada di Desa Dayu Kecamatan Karusen Janang merupakan sebuah tradisi yang memiliki nilai dan makna tersendiri bagi masyarakat kalangan orang tua, tetapi mirisnya para generasi muda tidak begitu perduli dan menganggap hal tersebut biasa saja.

\section{Tradisi Upacara Ritual Miwit Abeh}

Dalam upacara tradisional terkhususnya tradisi ritual miwit abeh, menerima perbedaan itu bukan suatu beban yang mengurangi hikmatnnya upacara.Hal ini menjelaskan bagaimana ritual miwit abeh secara fungsional berguna untuk menyalurkan dan menjembatani emosi yang bersifat individual, untuk penyembahan, kompromi dengan benda-benda gaib.

Di mulai pada tahun 1300 awal mulanya keramat patung abeh tersebut sampai dengan tahun 1956prosesi ritual miwit abeh dilaksanakan hanya tiga hari lamanya karena sebelum prosesi ritual miwit abeh ini dimulai terlebih dahulu masyarakat bersama mantir adat dan belian melakukan "Basagur Miwit Sarit Sampar" yaitu prosesi ritual menjauhkan diri dari malapetaka,sakit penyakit,dan bahaya yang 
mengancam masyarakat Desa Dayu, prosesi ini di lakukan disetiap batas Desa Dayu dan desa lain yang dilaksanakan setiap satu tahun sekali beriringan dengan prosesi ritual miwit abeh tepatnya pada bulan juli setelah panen padi. Setelah prosesi basagur selesai dilanjutkan dengan melakukan rapat bersama dengan Kepala Desa dan Perangkat Desa lainnyaterkait pelaksanaan ritual miwit abeh dimulai dengan membahas pembersihan Balai Adat, memanggil wadian (Belian), keluarga keturunan abeh dan mempersiapkan "Pidudukan" yaitu persyaratan sesajian mentah atau bahan/simbol ritual miwit abeh yaitu berupa :

1. Manu biring 1

2. Ketupat pakinkin 9.

3. Gula merah bulat.

4. Niuy bulat.

4. Sangku dite longkong.

5. Tumpi kaluwit.

6. Bakam ilau tabingkar kalanis.

7. Weah kuning

Adapun tujuan dilaksanakan prosesi ritual miwit abeh tidak hanya memberi makan tetapi juga masyarakat dipersilahkan mengikuti upacara tersebut serta bernazar ataupun menahur hajad atas apa yang diminta dan yang telah dipenuhi kepada Patung Abeh tersebut.

\section{Kesimpulan}

Pemerintah Desa sangat berperan aktif dalam mempertahankan budaya miwit abeh sebagai salah satu warisan luhur yang harus dilestarikan begitu juga dengan masyarakat juga turut aktif dalam ikut terlibat dalam melaksanakan ritual ini, budaya ini seharusnya dipertahankan agar dapat menjadi salah satu daya tarik bagi desa Dayu.

\section{Referensi}

August 2014 oleh icci albarn.Label: Kebudayaan Tradisi.

Ayatrohaedi, 1936 "Kepribadian Budaya Bangsa (Lokal Genius)"

Jakarta: Pustaka Budaya

Budhisantoso, S. 1991 "Corak Kebudayaan Indonesia". Studi Indonesia, 01:1162. Durrenberger,

Bobin, A. B. et al (eds), Monografi Daerah Jawa Tengah Jakarta: Proyek Pengembangan Media Kebudayaan Dept. P \& KRI, n.

Geertz, H. 1981. Aneka Budaya dan Komunitas di Indonesia. Jakarta: Yayasan Ilmu-Ilmu Sosial. 